\title{
ON THE OCCASION OF THE DEATH OF \\ Prof. Dr. PHIL. Siegfried Jost CASPER (1929-2021)
}

\author{
JÜRG STEIGER • Prof. em. Dr. med. • Bern・Switzerland • juergsteiger@bluewin.ch
}

In 1965 I wrote my Matura thesis on Pinguicula and in the following years obtained practically all publications on this genus. As the culmination of my search for literature, I found the Pinguicula monograph by Siegfried Jost Casper, which appeared in 1966 but was soon out of print, at a Berlin science antiquarian bookstore. Through the publishing house I was able to find the address of the author whom I first contacted by letter in September 1969. Telephone contact or a visit to Jena, where Casper lived, was impossible in view of the political situation in the former GDR. Since then, around 100 letters and later 312 e-mails to and from Casper have accumulated. The Pinguicula monograph was actually his so-called habilitation thesis with regard to an appointment as professor at the Friedrich Schiller University in Jena. I only found out why that failed after the fall of the Berlin Wall (1989) on the occasion of Casper's visit to Bern (which was later followed by several mutual visits): Because of the spying by the GDR Stasi, written reports about private life would have been too dangerous. Disgusted by the Ulbricht politics of the GDR, Casper and his family made meticulous preparations in 1962 for an escape to the West. On the evening before the escape, he informed the only person, his best friend of many years, a professor at the University of Jena, why he would no longer appear at the institute the next morning. This supposedly most trustworthy 'friend' advised the Stasi that same night: The cleverly prepared escape failed and Casper lost his tenure, his job, and the expected habilitation. Casper's wife had to testify against him in order to keep her part-time job as a hydrologist. For 30 years under most miserable financial conditions, Casper reactivated his profound knowledge of music and wrote several publications on works by Johann Sebastian Bach, which our musicology professor of the University of Bern classified as "absolutely professional". Thanks to the good trade relations between the GDR and Cuba (sugar agreement), Casper, although not allowed to travel, was able to participate in joint investigations of the Pinguicula taxa of Cuba, during which he described seven new species formally despite adverse conditions. In the description of the species, apart from the meticulous morphological and distribution details, I was particularly impressed by his excellent knowledge of Latin. In addition to his mother tongue German, Casper spoke and wrote English, Russian, French, and had a basic knowledge of Italian. In 1992, Casper was finally rehabilitated by the rector of the University of Jena, so that at the age of almost 64 he could fully resume his scientific work on the taxonomy, systematics and genetics of the genus Pinguicula. As professor and director of the Botanical Garden at the Institute for Special Botany at the University of Jena, he was actively supported by Prof. Mark Hellwig and Ms. Rosemarie Stimper, with whom he made numerous chromosome counts and performed DNA sequencing. The scientific achievements of Jost Casper are enormous: In addition to the 223-page Pinguicula monograph (1966), he published the 2 volumes on Tracheophytes for 'Freshwater flora of Central Europe' in 1980-81 as a joint work with Prof. H.-D. Krausch, the chapters on algae in 'Urania Pflanzenreich' (1991), and a series of publications on various botanical topics, plus 25 original descriptions/new combinations of Pinguicula species and subspecies! These are $P$. agnata, $P$. apuana, $P$. baezensis, $P$. balcanica, $P$. balcanica subsp. pontica, $P$. bissei, $P$. cayophyllacea, $P$. cubensis (with Urquiola), . cyclosecta, $P$ grandiflora subsp. rosea (Mutel), $P$. imitatrix, $P$. infundibuliformis, P. jaraguana, $P$. kondoi, P. lippoldii, P. longifolia subsp. caussensis, P. longifolia subsp. reichenbachiana (Schindler), P. mariae, P. moaensis, P. nevadensis (H.Lindb.), P. orthoceras, P. poldinii (with Steiger), P. rosmarieae, $P$. sharpii (with Kondo), and P. toldensis. Pinguicula casperi H.D.Suarez \& Zamudio (2018) from Mexico and P. casperiana M.B.Crespo et al. (2020) from Spain have been named in his honour. Casper also found out from an inconspicuous tiny note on an excursion drawing from the 16th century that the name Pinguicula had been created by Conrad Gessner (1516-65) using a plant from Mt. Pilatus near Lucerne. After both his wife and Jost became seriously ill, the Casper couple moved to Dresden, where they were looked after by relatives. With Jost Casper's death, Botany has lost a highly educated, spirited, obstinate, passionate and incredibly resilient scientist of international standing. His herbarium specimens are conserved at the Herbarium Haussknecht in Jena. 